\title{
Pattern of infants' feeding and weaning in Suez Governorate, Egypt: an exploratory study
}

Laila Kamel, ${ }^{1}$ Hend Sabry, ${ }^{1}$ Marwa Ismail ${ }^{1}$ and Ghada Nasr $^{1}$

${ }^{1}$ Department of Public Health and Community Medicine, Faculty of Medicine, Cairo University, Cairo, Egypt (Correspondence to: Laila Mahmoud Kamel; hendalysabry@yahoo.com).

\begin{abstract}
Background: Breastfeeding and proper weaning contribute to achievement of the Sustainable Development Goals. In Egypt, by age 4-5 months, only $13 \%$ of infants are exclusively breastfed. A survey conducted in Egyptian hospitals concluded that many of the 10 steps to support successful breastfeeding were not executed correctly and other steps were not executed at all.
\end{abstract}

Aims: To explore the patterns of feeding and weaning among infants in Egypt, and identify their determinants, to improve practice and promote children's nutritional status.

Methods: A cross-sectional analytical study of 333 mother-infant pairs attending two primary healthcare (PHC) centres for vaccination sessions between April 2017 and June 2018. Mothers were interviewed using a structured questionnaire.

Results: Almost all infants were born in hospitals. Exclusive breastfeeding was not widely practiced. Prelacteal feeding was a common malpractice. The majority of mothers initiated artificial feeding during the first month of life. Rural mothers tended to introduce different foods earlier than urban mothers did. Minimum dietary diversity was achieved by $50.9 \%$ of urban infants aged $\geq 6$ months ( $\geq 4$ food groups), compared with $25.9 \%$ of rural infants. Minimum recommended meal frequency for age was fulfilled for $51.9 \%$ of urban and $29.6 \%$ of rural infants. More than $85 \%$ of mothers expressed their need for additional knowledge, and more than half identified the PHC centre as the appropriate source for information.

Conclusions: Our study reflects deficiency in maternal practice regarding breastfeeding and weaning, despite being regular visitors to the PHC centre.

Keywords: breast feeding, complementary feeding, exclusive breastfeeding, Egypt, weaning

Citation: Kamel L; Sabry H; Ismail M; Nasr G. Pattern of infants' feeding and weaning in Suez Governorate, Egypt: an exploratory study. East Mediterr Health J. 2020;26(8):909-915. https://doi.org/10.26719/emhj.20.045

Received: 06/01/19; accepted: 10/04/19

Copyright ( ) World Health Organization (WHO) 2020. Open Access. Some rights reserved. This work is available under the CC BY-NC-SA 3.0 IGO license (https://creativecommons.org/licenses/by-nc-sa/3.o/igo)

\section{Introduction}

Early childhood health and nutrition form the foundation for the well-being of the future generation. Breastfeeding and proper weaning contribute to the achievement of the Sustainable Development Goals (SDGs); they improve nutrition (SDG2), decrease child mortality (SDG3), support cognitive development and education (SDG4), and decrease the future risk of development of noncommunicable diseases (SDG3). Breastfeeding also provides an economic benefit to the family and country, thus contributing to SDG1. It also lowers healthcare costs, improves education and increases productivity (1).

Despite knowing the benefits of breastfeeding, only $40 \%$ of children younger than 6 months are exclusively breastfed (2). The Global Breastfeeding Scorecard found that only 23 countries have $>60 \%$ exclusive breastfeeding for 6 months (3). Globally, only $45 \%$ of newborn infants initiate breastfeeding within the first hour of birth and about $75 \%$ of children continue breastfeeding till 12-15 months (4). The Egyptian Demographic Health Survey (EDHS), 2014 showed that $96 \%$ of infants are ever breastfed; however, exclusive breastfeeding is little practiced. By age $4-5$ months, only $13 \%$ of infants are exclusively breastfed (5). A 2015 survey conducted in 33 Egyptian hospitals concluded that many of the 10 steps for promotion of breastfeeding in baby-friendly hospitals were not executed correctly and other steps were not executed at all (6).

Introducing nutritionally adequate complementary (solid) foods at age 6 months, together with continued breastfeeding is essential for optimal child growth (7). The World Health Organization (WHO) recommends that, for healthy growth, infants must receive at least 4 food groups each day from 7 essential food groups (8).

The objectives of this study were to explore the patterns of feeding and weaning among infants in Egypt, and to identify their determinants, to improve practice and promote children's nutritional status.

\section{Methods}

This was a cross-sectional analytical study conducted over a period of 15 months, from April 2017 to June 2018. The study included 333 mother-infant pairs attending vaccination sessions at 2 primary healthcare $(\mathrm{PHC})$ centres in Suez Governorate, Egypt [El-Tawffikia PHC (urban centre) and Qariat-Amer PHC (rural centre)]. 
The sample size was calculated using Epi-info version 7.2.2.6 software with under 5 stunting prevalence of $21 \%$ (5) and a margin of error/precision (d) no more than 0.05 . The total required sample size was calculated to be 256 from both PHC centres, and each cluster size equalled 128 . Finally, the study was actually conducted on a sample of 333 mother-infant pairs.

Eligible mothers were interviewed using a structured questionnaire (attached as Supplementary Material) that included sociodemographic data for mothers and children, which was adapted from the Fahmi and ElSherbini Sociodemographic Score (9). Feeding practices included: breastfeeding (child receiving breast milk); artificial feeding (child feeding on a breast-milk substitute); complementary feeding (child receiving both breast milk and solid/semisolid or soft foods); weaning (introduction of complementary feeding) pattern; and 24-hour dietary recall; which were adapted from the WHO/United Nations Children's Fund (UNICEF) tool (8). Answers were coded prior to data collection to facilitate data entry. Validation was through use of pretested questionnaires and by experts' opinions. Pilot testing was done on 20 infants (not included in the worked upon sample) to check clarity of the used questions, and to estimate the average time needed for each mother to answer the questions.

Precoded data were entered into SPSS version 24 to be cleaned and analysed. Quantitative variables were summarized using mean, median and standard deviation. Qualitative variables were summarized using frequency and percentage. Comparison between groups was performed using the $\mathrm{c}^{2}$ test for qualitative variables and independent sample $t$ test and Mann-Whitney test for quantitative variables. A $\mathrm{z}$ test for 2 proportions was used for indicators. $P<0.05$ was considered statistically significant.
Mothers were informed about the nature of the study and asked to participate. The data collection was anonymous and all responses were confidential. Oral consent was sought from the participants before the study. Participation in the study was optional and not required for accessing other services. The study was approved by the Research Ethics Committee of the Department of Public Health, Faculty of Medicine, Cairo University (s-4-2017).

\section{Results}

The study included infants aged 2-23 months attending for vaccination. Age and sex distribution did not differ significantly between the PHC centres.

All parents were literate in urban areas. In rural areas, $12(6.6 \%)$ of fathers and $17(9.4 \%)$ of mothers were illiterate. All fathers were working, except 2 in rural areas. More of the urban mothers were working: $26(17.2 \%)$ urban versus $12(6.6 \%)$ rural. Family size tended to be smaller in urban areas; $82(45.1 \%)$ families had $\geq 5$ members in rural areas compared with $51(33.8 \%)$ in urban areas. In general, urban families had a higher socioeconomic level. All these differences were significant.

Sixty-nine $(20 \%)$ infants were within a short birth spacing period after the last pregnancy ( $<2$ years) in both urban and rural areas. Child loss was significantly more frequently reported in rural than in urban areas $(9.3 \%$ vs $2.6 \%$ ). All infants were born in hospitals except for 5 infants in rural areas who were born at home.

Table 1 describes breastfeeding practices among urban and rural mothers. Most infants were ever breastfed. Exclusive breastfeeding was not widely practiced. Among 92 infants aged < 6 months, only 17 (18.5\%) were exclusively breastfed: $11(24.4 \%)$ in urban areas and 6 $(12.8 \%)$ in rural areas. Prelacteal feeding was a common malpractice, with a higher frequency among mothers

\begin{tabular}{|c|c|c|c|c|c|c|}
\hline \multirow[t]{2}{*}{ Breastfeeding pattern } & \multicolumn{2}{|c|}{$\begin{array}{c}\text { Urban } \\
\text { (151) }\end{array}$} & \multicolumn{2}{|c|}{$\begin{array}{c}\text { Rural } \\
\text { (182) }\end{array}$} & \multicolumn{2}{|c|}{$\begin{array}{l}\text { Total } \\
\text { (333) }\end{array}$} \\
\hline & No. & $(\%)$ & No. & $(\%)$ & No. & $(\%)$ \\
\hline Ever breast feeding & 146 & 96.7 & 182 & 100 & 324 & 97.3 \\
\hline Initiation of breast feeding: & 146 & 100 & 178 & 100 & 324 & 100 \\
\hline Within 1 hour & 71 & 48.6 & 84 & 47.2 & 155 & 47.8 \\
\hline $2-24$ hours & 62 & 42.5 & 70 & 39.2 & 132 & 40.7 \\
\hline From day 2 & 13 & 7.9 & 24 & 13.6 & 37 & 11.5 \\
\hline Prelacteal feeding & 92 & 63.0 & 129 & 72.5 & 221 & 68.2 \\
\hline \multicolumn{7}{|l|}{ Duration of exclusive breastfeeding: } \\
\hline$<1$ month & 59 & 40.4 & 72 & 40.5 & 131 & 40.4 \\
\hline$\geq 1$ month & 87 & 59.6 & 106 & 59.5 & 193 & 59.6 \\
\hline Exclusive breastfeeding among infants aged $<6$ months & 45 & 100 & 47 & 100 & 92 & 100 \\
\hline Infants 0-5 months of age who are receiving breast milk only & 11 & 24.4 & 6 & 12.8 & 17 & 18.5 \\
\hline
\end{tabular}


in rural areas. The commonest cause of never receiving breast milk was maternal illness in rural areas (50\%), compared with breast problems (40\%) and infant illness (40\%) in urban areas. In general, there were no significant differences in breastfeeding practices between mothers in urban and rural areas, although urban residents were slightly better.

Artificial milk was fed to more than $40 \%$ of infants in urban and rural areas (Table 2). The majority of mothers (72.5\%) initiated artificial feeding during the first month of life. There were no significant differences between urban and rural mothers in artificial feeding practices. The most important reasons for introducing artificial feeding were: infant not gaining weight (23.5\%), twin baby $(23.5 \%)$, insufficient breast milk (22.1\%) and infant illness $(17.4 \%)$. Out of the 149 infants receiving artificial feeding, 31 obtained it from the PHC centre only, 94 from the pharmacy, and the remainder from either source. A bottle was used for artificial feeding or other fluids of 89 (58.9\%) urban and 120 (65.9\%) rural infants, with no significant difference.

The first foods to be introduced to infants were milk products, vegetables, fruit, potatoes and bread at a median age of 6 months (Table 3). In general, rural mothers tended to introduce different foods earlier than urban mothers. Except for milk, milk products and beans there was no significant difference between urban and rural areas. For fish and potatoes, the difference was marginally significant between urban and rural areas.

Based on 24-hour recall, 54 (50.9\%) urban infants aged $\geq 6$ months achieved minimum dietary diversity $(\geq 4$ food groups), compared with 35 (25.9\%) rural infants; the difference was significant. Among non-breastfed infants, $21(71.9 \%)$ urban and $20(62.9 \%)$ rural infants received $\geq 2$ milk feeds on the previous day but the difference was not significant. Minimum recommended meal frequency for infants aged $\geq 6$ months was fulfilled for 55 (51.9\%) urban and $40(29.6 \%)$ rural infants, and the difference was significant.

More than $85 \%$ of mothers (285 in both centres) expressed their need for additional knowledge, and > $50 \%$ ( 178 in both centres) identified the PHC centre as the appropriate source for information. Social media and the Internet were the preferred sources of information for 48 (31.8\%) urban mothers and 26 (14.3\%) rural mothers. Only $107(32.1 \%)$ mothers knew the right meaning of exclusive breastfeeding, and 161 (48.3\%) defined weaning correctly. Infant age 6 months was mentioned as appropriate for introducing food by $292(87.7 \%)$ mothers: 152 (92.7\%) urban and $152(83.5 \%)$ rural $(P \leq 0.05)$. Almost 90\% (298 mothers) said that infant age 2 years was suitable for termination of breastfeeding. Three quarters of mothers ( $n=247$ ) would not stop breastfeeding during their infant's illness. In general, urban mothers' knowledge was slightly better. More urban than rural mothers knew the correct meaning of exclusive breastfeeding [57 (37.7\%) urban vs 50 (27.5\%) rural] and weaning [76 (50.3\%) urban vs 85 (46.7\%) rural]; suitable age to introduce food [140 (92.7\%) urban vs $152(83.5 \%)$ rural]; not to introduce cow's milk before the first year [125 (82.8\%) urban vs 141 $(77.5 \%)$ rural]; and not to stop breastfeeding in illness [115 (76.2\%) urban vs 132 (72.6\%) rural].

\begin{tabular}{|c|c|c|c|c|c|c|}
\hline \multirow[t]{2}{*}{ Artificial feeding pattern } & \multicolumn{2}{|c|}{$\begin{array}{c}\text { Urban } \\
\text { (151) }\end{array}$} & \multicolumn{2}{|c|}{$\begin{array}{c}\text { Rural } \\
\text { (182) }\end{array}$} & \multicolumn{2}{|c|}{$\begin{array}{l}\text { Total } \\
\text { (333) }\end{array}$} \\
\hline & No. & $(\%)$ & No. & $(\%)$ & No. & $(\%)$ \\
\hline Ever artificial feeding & 68 & 45.1 & 81 & 44.5 & 149 & 44.7 \\
\hline Age of starting: & 68 & 100 & 81 & 100 & 149 & 100 \\
\hline$<1$ month & 50 & 73.4 & 58 & 71.6 & 108 & 72.5 \\
\hline 1-2 months & 6 & 8.8 & 12 & 14.8 & 18 & 12.1 \\
\hline$\geq 2$ months & 12 & 17.8 & 11 & 27.2 & 23 & 15.4 \\
\hline \multicolumn{7}{|l|}{ Reasons for artificial feeding: } \\
\hline Infant not gaining weight & 15 & 22.1 & 20 & 24.7 & 35 & 23.5 \\
\hline Twin baby & 15 & 22.1 & 20 & 24.7 & 35 & 23.5 \\
\hline Insufficient maternal milk & 15 & 22.1 & 18 & 22.2 & 33 & 22.1 \\
\hline Infant illness & 13 & 19.1 & 13 & 16.1 & 26 & 17.4 \\
\hline Mother's illness & 4 & 5.8 & 5 & 6.2 & 9 & 6.0 \\
\hline Baby refused to breastfeed & 4 & 5.8 & 4 & 4.9 & 8 & 5.4 \\
\hline Mother going work & 2 & 3.0 & 1 & 1.2 & 3 & 2.1 \\
\hline \multicolumn{7}{|l|}{ Source for artificial feeding: } \\
\hline Primary health centre & 13 & 19.1 & 18 & 22.2 & 31 & 20.8 \\
\hline Pharmacy & 48 & 70.6 & 46 & 56.8 & 94 & 63.1 \\
\hline Primary health centre and pharmacy & 7 & 10.3 & 17 & 21.0 & 24 & 16.1 \\
\hline
\end{tabular}




\begin{tabular}{|c|c|c|c|c|c|c|c|c|c|}
\hline \multirow[t]{3}{*}{ Food introduced } & \multicolumn{4}{|c|}{$\begin{array}{l}\text { Urban } \\
n=151\end{array}$} & \multicolumn{4}{|c|}{$\begin{array}{c}\text { Rural } \\
n=182\end{array}$} & \multirow[t]{3}{*}{$\mathbf{P}^{*}$} \\
\hline & \multicolumn{2}{|c|}{ Received } & \multirow[t]{2}{*}{ Median } & \multirow{2}{*}{$\begin{array}{c}\text { Range } \\
\text { Min-Max }\end{array}$} & \multicolumn{2}{|c|}{ Received } & \multirow[t]{2}{*}{ Median } & \multirow{2}{*}{$\begin{array}{c}\text { Range } \\
\text { Min-Max }\end{array}$} & \\
\hline & No & $\%$ & & & No & $\%$ & & & \\
\hline \multicolumn{10}{|l|}{ Milk \& milk products } \\
\hline Milk & 64 & 42.4 & 12.0 & $4-21$ & 71 & 39.0 & 9.0 & $3-16$ & 0.019 \\
\hline Milk products & 97 & 64.2 & 6.0 & $2-18$ & 132 & 72.5 & 6.0 & $2-12$ & 0.001 \\
\hline \multicolumn{10}{|l|}{ Animal food: } \\
\hline Meat & 80 & 53.0 & 9.0 & $5-15$ & 98 & 53.4 & 9.0 & $6-15$ & 0.122 \\
\hline Fish & 80 & 53.0 & 9.0 & $5-17$ & 89 & 48.9 & 9.0 & $6-12$ & 0.055 \\
\hline Liver & 74 & 49.0 & 8.5 & $3-16$ & 74 & 49.0 & 8.0 & $5-15$ & 0.262 \\
\hline Eggs & 91 & 60.3 & 8.0 & 4- 14 & 91 & 60.2 & 7.0 & $3-12$ & 0.064 \\
\hline Beans & 75 & 49.7 & 8.0 & $4-15$ & 110 & 60.4 & 7.0 & $4-12$ & 0.026 \\
\hline Vegetables \&Fruits & 102 & 67.5 & 6.0 & $3-12$ & 131 & 72.0 & 6.0 & $3-12$ & 0.533 \\
\hline Potato & 101 & 66.9 & 6.0 & $4-13$ & 129 & 70.9 & 9.0 & $2-10$ & 0.055 \\
\hline Bread & 106 & 70.2 & 6.0 & $2-13$ & 137 & 75.3 & 6.0 & $2-10$ & 0.848 \\
\hline
\end{tabular}

\section{Discussion}

Early feeding pattern forms the foundation of health throughout the lifespan of the individual, and breastfeeding is the cornerstone. In our study, ever breastfeeding was practiced by $97.3 \%$ of mothers; slightly more in rural areas. Nearly the same pattern was reported by EDHS 2014 (5), where ever breastfeeding was practiced by $95.7 \%$ of mothers. The difference may be related to sampling differences.

Early initiation greatly affects the whole period of breastfeeding (10). It is associated with improved newborn survival and lowers hospital-acquired infection through colostrum (11). With $>1$ hour delay in initiation of breastfeeding, mothers are more likely to stop breastfeeding early (12). In our study, early initiation was practiced by $47.8 \%$ of mothers, and was slightly better in urban areas (48.6\% vs $47.2 \%$ in rural areas). In Minya District, a community-based study was conducted on 307 rural mothers whose youngest child was aged $\leq 2$ years, and $83.7 \%$ initiated breastfeeding within the first hour (13). This may have been due to the better communication and health education given in the Maternal and Child Health Centre under study. EDHS 2008 (14) reported $55.9 \%$ and EDHS 2014 (5) reported a much lower figure of $27.1 \%$. All urban deliveries and all except 5 rural deliveries were in hospital, which imposes a great responsibility on the hospital to support early initiation of breastfeeding as one of the 10 steps of baby-friendly hospitals (15).

Prelacteal feeding shortens the duration of any breastfeeding and exclusive breastfeeding, as well as carrying a risk of infection (4). Prelacteal feeding seems to be on the rise. EDHS 2008 (14) reported 46.6\%, EDHS 2014 (5) reported $61.2 \%$, and in the present study it was $68.2 \%$ (63.0\% in urban and $72.5 \%$ in rural areas). In Minya, the situation was better; the prevalence of prelacteal feeding among the rural population was $42.7 \%$ (13). The Population and Family Health Survey conducted in Jordan in 2012 reported a similar prevalence as in our study (16). High rates of prelacteal feeding are usually due to the traditional misconception that the colostrum volume is small. Unfortunately, some of the healthcare providers in our study had the same misconcept; all urban and all except 5 rural mothers had hospital deliveries, and their infants received prelacteal feeding. Some misconceptions about colostrum are related to its colour; some people think it is dirty, or the milk has "gone bad" after being in the breast too long. In fact colostrum perfectly matches newborn's stomach capacity and is rich in antibodies and nutrients (4).

Breast milk is the only requirement in the first 6 months of life. It supplies the infant with necessary nutrients and protects against infection. Despite its importance, exclusive breastfeeding is decreasing over time. EDHS 2008 (14) reported 53.2\% of infants aged 0-5 months were exclusively breastfed but the prevalence decreased to $39.7 \%$ in EDHS 2014 (5). In the Minya study, the prevalence was $32.2 \%$ (13). In a study done among attendees of outpatient paediatric clinics in Cairo the prevalence was $49.7 \%$ (17). The present study revealed that, among infants aged 0-5 months, only $18.5 \%$ were exclusively breastfed (24.4\% among urban and $12.8 \%$ among rural infants). Our findings are disappointing; contrary to the studies done in the community or outpatient clinics, mother-infant pairs were recruited from attendees of PHC centres that should have provided them with health education about proper breastfeeding. In the present study, more than $85 \%$ of mothers expressed their need for additional knowledge, and only a third knew the right meaning of exclusive breastfeeding.

Ever use of artificial feeding was reported in $44.7 \%$ of mothers; almost three quarters of them started in the first month, and 85\% within the first 2 months. EDHS 2014 (5) reported that $12.5 \%$ of infants aged $0-5$ months received artificial milk. In Jordan, the prevalence of artificial feeding was almost the same as in our study (45\%) (16). The Egyptian Ministry of Health dispenses artificial 
milk free of charge to infants in the first 6 months who really need it; however, $63.1 \%$ buy it from the pharmacy. The availability of low-price milk substitutes encourages mothers toward inappropriate introduction of artificial milk. The widespread introduction of artificial milk was greatly affected by the Egyptian national code for the marketing of breastmilk substitutes, which was released in 1994 but was never enforced (18).

A bottle was used for artificial feeding or other fluids by $58.9 \%$ of urban and $65.9 \%$ of rural mothers, with no significant difference between the groups. EDHS 2014 (5) reported around 3 in 10 children aged $<6$ months were being bottle fed.

The first foods to be introduced to infants were vegetables, fruits, potatoes, milk products and bread at a median age of 6 months. Six months as the appropriate age of introducing food was mentioned by $87.7 \%$ of mothers (92.7\% urban and $83.5 \%$ rural). However, in practice, rural mothers tended to introduce different foods earlier than urban mothers did. Except for milk and milk products, there was no significant difference between urban and rural areas. Almost all infants (94.1\%) in our study received solid, semisolid or soft foods at age 6-8 months, which is higher than the national figure of $71 \%$ reported in EDHS 2014 (5). This can be explained by the higher socioeconomic level of the studied community where mothers do not rely on the prolonged duration of exclusive breastfeeding without adding complementary foods as an additional source of nutrients (19-21). A similar result was reported in Jordan in 2012 (91\%) (16).

Four food groups are considered as the minimum acceptable diversity in feeding for infants and young children (8). In our study, $37 \%$ of infants were given foods of appropriate diversity, which is higher than in a study conducted in Nigeria 2016 that concluded that 31\% of infants had achieved the minimum diversity score (22), but is still lower than the EDHS 2014 report of $43 \%$ (5).

We found that $39.4 \%$ of infants achieved minimum meal frequency per day. This is close to the results reported by the study in Nigeria that concluded that $36 \%$ of infants had achieved the minimum recommended meal frequency (22) but is still lower than the EDHS 2014 report of $60 \%(5)$.

Mothers' knowledge is expected to reflect practice. More than $85 \%$ of mothers expressed their need for additional knowledge, and more than half identified the $\mathrm{PHC}$ centre as the appropriate source for information.

\section{Conclusion}

Our study reflects deficiency in maternal practice despite being regular visitors to the PHC centre for vaccination, and their identification of the centre as the appropriate source for them to receive health education. Both this and lack of early initiation of breast feeding in hospitals represent lost opportunities for maternal health education and support. This imposes a great responsibility on PHC centres to improve their role in health promotion and education through the critical 1000 days of life extending from pregnancy to the first 2 years of life.

Funding: None.

Competing interests: None declared.

\section{Profil de l'alimentation et du sevrage des nourrissons dans le gouvernorat de Suez (Égypte) : une étude exploratoire}

\section{Résumé}

Contexte : L'allaitement au sein et un sevrage approprié contribuent à la réalisation des Objectifs de développement durable. En Égypte, à l'âge de 4 à 5 mois, seuls $13 \%$ des nourrissons sont exclusivement allaités au sein. Selon les résultats d'une enquête menée dans des hôpitaux égyptiens, les dix mesures visant à favoriser un allaitement au sein réussi n'étaient pas suivies correctement, voire pas appliquées du tout.

Objectifs : Étudier le profil de l'alimentation et du sevrage des nourrissons en Égypte et identifier ses déterminants afin de faire progresser les pratiques et de promouvoir l'état nutritionnel des enfants.

Méthodes : Une étude transversale analytique portant sur 333 couples mère-enfant fréquentant deux centres de soins de santé primaires (SSP) pour des séances de vaccination a été menée entre avril 2017 et juin 2018. Les mères ont été interrogées au moyen d'un questionnaire structuré.

Résultats: Presque tous les nourrissons étaient nés dans des hôpitaux. L'allaitement exclusif au sein n'était pas largement pratiqué. L'introduction d'aliments avant l'allaitement au sein était une faute courante. La majorité des mères avaient commencé l'alimentation artificielle au cours du premier mois de vie. Les mères vivant en zone rurale avaient tendance à introduire différents aliments plus tôt que les mères vivant en zone urbaine. Le niveau minimal de diversité alimentaire avait été atteint par 50,9\% des nourrissons vivant en zone urbaine âgés de six mois ou plus (quatre groupes d'aliments ou plus), contre $25,9 \%$ des nourrissons vivant en zone rurale. La fréquence minimale recommandée des repas en fonction de l'âge était respectée pour $51,9 \%$ des nourrissons vivant en zone urbaine et 29,6 \% des nourrissons vivant en zone rurale. Plus de $85 \%$ des mères ont exprimé le besoin d'acquérir davantage de connaissances et plus de la moitié ont reconnu que le centre de soins de santé primaires était la source d'information appropriée.

Conclusions : Notre étude reflète les carences des pratiques adoptées par les mères en matière d'allaitement au sein et de sevrage, malgré la fréquentation régulière d'un centre de soins de santé primaires. 


\section{نمط تغذية الرضَّع وفِطامهم في محافظة السويس، مصر : دراسة استكشافية \\ ليلى كامل، هند صبري، مروة إسهاعيل، غادة نصر

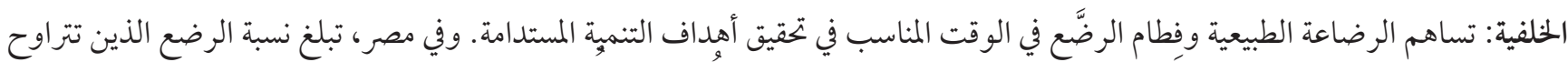

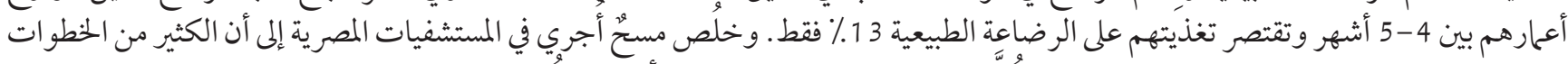

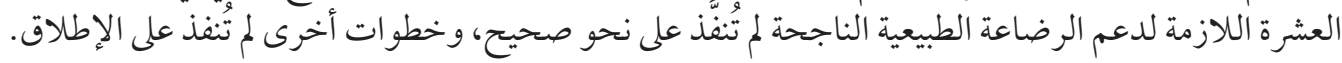

الأهداف: هدفت هذه الدراسة إلى استكشاف أنهاط التغذية والفطام بين الرضع في مصر، والوقوف على تححدِّدات ذلك لتحسين الملمارسة، وتعزيز الوضع التغذوي للأطفال.

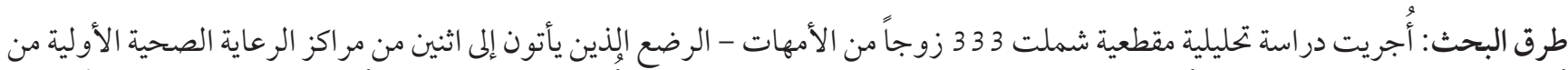

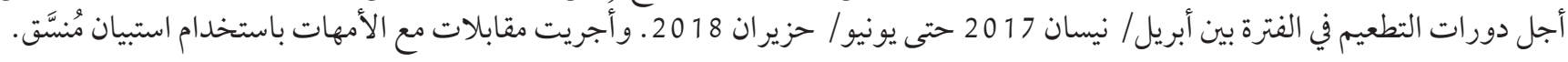

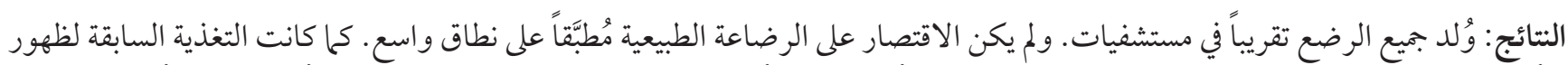

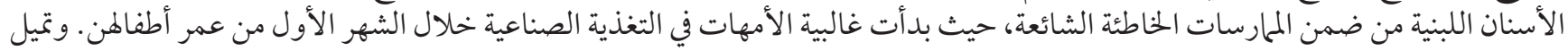

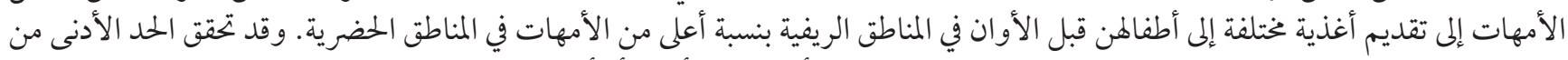

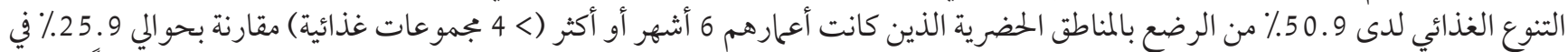

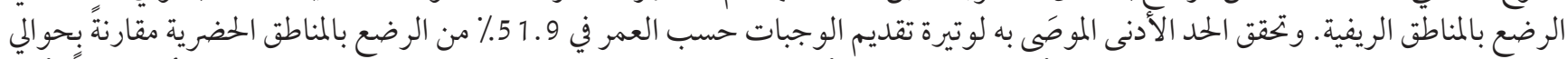

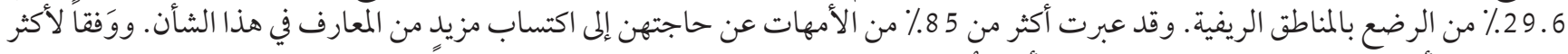

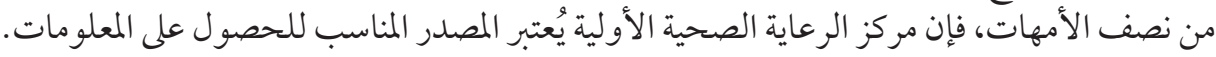

الاستنتاجات: تعكس هذه الدراسة قصوراً في ممارسات الأمهات في ما يتعلق بالرضاعة الطبيعية والفطام، وذلك على الرغم من زيارتهن لمركز

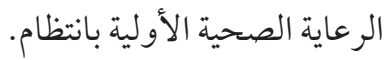

\section{References}

1. Adhanom Ghebreyesus T, Lake A. Breastfeeding is not a one-woman job [website]. World Health Organization; 2017 (http:// www.who.int/mediacentre/commentaries/world-breastfeeding-week/en/, accessed 20 February 2020).

2. Nourishing the SDGs, Global Nutrition Report. World Health Organization; 2017

3. Tracking progress for breastfeeding policies and programs: global breastfeeding scorecard. United Nations Children's Fund; World Health Organization; 2017. http://www.who.int/nutrition/publications/infantfeeding/global-bf-scorecard-2017/en/, accessed 20 February 2020).

4. Breastfeeding and complementary feeding [website]. United Nations Children's Fund; 2018 (https://www.unicef.org/nutrition/ index_breastfeeding.html, accessed 20 February 2020).

5. $\quad$ Egypt Demographic and Health Survey. Ministry of Health and Population; El-Zanatay and Associates; ICF International; 2014 (https://dhsprogram.com/pubs/pdf/FR302/FR302.pdf, accessed 20 February 2020).

6. Baby Friendly Multicenter Needs Assessment Survey (BFHI-MAS). Breastfeeding promotion, protection, and support. UNICEF/ WHO Baby Friendly Hospital Initiative. Revised updated and expanded for integrated care. General Department of Motherhood \& Childhood Care in Ministry of Health \& Population; Mother Child Friendly Care Association; United Nations Children's Fund, Egypt; 2016 (http://www.mcfcare.org/Articles/BF_multicenter_needs_assessment_survey.pdf, accessed 20 February 2020).

7. Infant and young child feeding. Adopting optimal feeding practices is fundamental to a child's survival, growth and development, but too few children benefit [website]. United Nations Children's Fund; 2016 (https://data.unicef.org/topic/nutrition/infant-and-young-child-feeding, accessed 20 February 2020).

8. Indicators for assessing infant and young child feeding practices. Part I: definition. World Health Organization; 2008 (https:// www.who.int/maternal_child_adolescent/documents/9789241596664/en/, accessed 20 February 2020).

9. Fahmi SI, EL-Sherbini AF. Determining simple parameters for social classification for health research. Bull High Institute Public Health. 1985;13:95-107.

10. Holmes A, Brown L, Hurst N. Establishing successful breastfeeding in the newborn period. Pediatr Clin North Am. 2013 Feb;6o(1):147-68. http://dx.doi.org/10.1016/j.pcl.2012.09.013 PMID: 2317806

11. NEOVITA Study Group. Timing of initiation, patterns of breastfeeding, and infant survival: prospective analysis of pooled data from three randomized trials. Lancet Glob Health. 2016 Apr;4(4):e266-75. http://dx.doi.org/10.1016/S2214-109X(16)00040-1 PMID:27013313 
12. Infant and young child feeding counselling: an integrated course. Trainer's guide. Geneva: World Health Organization; 2006 (https://apps.who.int/iris/bitstream/handle/10665/43567/9789241594769_eng.pdf;jsessionid=726215940A3B690ADo01E8E66537F$\mathrm{FE} 4$ ? sequence=3, accessed 20 February 2020).

13. Mohammed ES, Ghazawy ER, Hassan EE. Knowledge, attitude, and practices of breastfeeding and weaning among mothers of children up to 2 years old in a rural area in El-Minya governorate, Egypt. J Family Med Prim Care. 2014 Apr;3(2):136-40. http:// dx.doi.org/10.4103/2249-4863.137639 PMID:25161971

14. El-Zanaty F, Way A. Egypt Demographic and Health Survey 2008. Cairo: Ministry of Health; El-Zanaty and Associates; Macro International; 2009 (https://dhsprogram.com/pubs/pdf/FR220/FR220.pdf, accessed 20 February 2020).

15. Implementation guidance. Protecting, promoting and supporting breastfeeding in facilities providing maternity and newborn services: the revised Baby-Friendly Hospital Initiative. World Health Organization; United Nations Children's Fund; 2018 (http:// www.who.int/nutrition/publications/infantfeeding/bfhi-implementation-2018.pdf, accessed 20 February 2020).

16. Jordan Population and Family Health Survey 2012. Amman: Department of Statistics;

17. Calverton, MD: ICF International; 2013 (https://dhsprogram.com/pubs/pdf/fr282/fr282.pdf, accessed 20 February 2020).

18. Kandeel WA, Rabah TM, Zeid DA, El-Din EMS, Metwally AM, Shaalan A, et al. Determinants of Exclusive Breastfeeding in a Sample of Egyptian Infants. 2018 Open Access Maced J Med Sci. 2018 Feb 20;6(10):1818-23. https://doi.org/10.3889/oamjms.2018.359.

19. Report on the situation of infant and young child feeding in Egypt. International Baby Food Action Network; Geneva Infant Feeding Association; 2013 (https://tbinternet.ohchr.org/Treaties/CESCR/Shared\%20Documents/EGY/INT_CESCR_NGO_ EGY_14089_E.pdf, accessed 20 February 2020).

20. Carvalhaes M, Parada C, Costa M. Factors associated with exclusive breastfeeding in children under four months old in Brazil. Rev Latino-Am Enfermagem, 2007 Jan-Feb;15(1):62-9. https://doi.org/10.1590/S0104-11692007000100010

21. Desmond C, Bland R, Boyce G, Coovadia H, Coutsodis A, Rollins N, et al. Scaling-up exclusive breastfeeding support programs: the example of KwaZulu-Natal. PLoS One. 2008 Jun 18;3(6):e2454. http://dx.doi.org/10.1371/journal.pone.0002454. PMID:18560596

22. Salami L. Factors influencing breastfeeding practice in Edo State, Nigeria. Af J Food Agric Nutr Dev. 2006;6(2):1-12. https://www. ajol.info/index.php/ajfand/article/view/71755

23. Udoh EE, Amodu OK. Complementary feeding practices among mothers and nutritional status of infants in Akpabuyo Area, Cross River State Nigeria. Springerplus. 2016 Dec 5;5(1):2073. http://dx.doi.org/10.1186/s40064-016-3751-7 PMID:28018781 